\title{
Event Differentiation In Service Science
}

\author{
Harry Katzan, Jr., Savannah State University
}

\begin{abstract}
In service science, a formal methodology is needed to distinguish one service from another and to define classes of services. A DNA of services is proposed consisting of a service DNA sequence of five letters corresponding to a five-dimensional linear scale. Each type of service is assigned a DNA sequence. If two services have the same DNA sequence, then they are in the same service class. The methodology provides an association between services, service models, and service systems.
\end{abstract}

\section{INTRODUCTION}

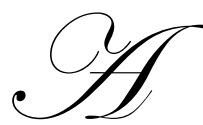

service is a socially designed and constructed form of activity in which a provider and a client collaborate to create economic value. In order to fully develop a science of services, a methodology is needed to distinguish one service from another and to define classes of services. A DNA of services is proposed consisting of a service DNA sequence of five letters corresponding to a linear scale associated with five service dimensions. Accordingly, each type of service is assigned a DNA sequence, such as DACAD, which is the DNA sequence for the physician/patient service model. If two services have the same DNA sequence, then they are in the same service class. The methodology essentially provides an association between services, service models, service systems, and service innovation.

\section{CONCEPTS, CLASSES, AND SERVICE EVENTS}

The basic question underlying services is, "Where do they come from?" It would appear that one entity simply makes up a service and another entity pays for it - in one way or another - when that service is engaged. As we shall see, it is more complicated than that. It is important to recall at this point that an entity can be a person, group, organization, and so forth, as long as the client entity can interact with the provider entity to create the mutual values to which we have referred previously. Both entities bring something to the service event and receive something when that activity has been completed.

\section{The Notion Of A Service Model}

Since a service is socially-created phenomena, then some "needs" research must take place in order to create a template for the corresponding service event. At an elementary level, a service template is formed through a commonly-used innovation technique known as observational research. On the other hand, it may result from extensive research and testing in a laboratory established for that purpose. Regardless, the service template, which we will refer to as a "service model," must come from somewhere.

To determine where a service comes from, we have to bring into play the notion of a concept and also restrict our thinking to a certain area of awareness. We can view the process as one of viewing the world through a special lens so that we only see what we are interested in. Within this special world, we develop concepts that eventually lead to classes of service.

\section{Concepts}

A concept is an abstract idea or mental representation that facilitates the recognition of and reference to objects in a specific area of interest. Concepts are important because they allow us to omit the differences between 
things by abstracting their common characteristics. Thus, a concept is a mental phenomenon that allows us to identify and develop objects and processes in our world.

\section{Service Classes And Events}

Concepts lead to classes that lead to objects. A class is a material representation of a concept and an object is an instance of a class. Here is a hypothetical example from the personal services domain:

Service Universe: Services performed on a person

Service Concept: Medical provisioning

Service Class: Physician/patient

Service Event: Individual visit to the doctor

In this instance, the service model is "physician/patient" conceptualized as medical provisioning within the service universe "services performed on a person." Here is another hypothetical service model:

Service Universe: Services performed on a possession of a person or an organization

Service Concept: Custodial provisioning

Service Class: Office maintenance

Service Event: Daily off-hours cleaning of executive suite

The service model is "office maintenance" conceptualized as custodial provisioning within the service universe "services performed on a possession of a person or an organization."

Service characteristics, such as these, delimit the extent of service models.

\section{SERVICE DIMENSIONS}

Accepting the fact that a service universe engenders service concepts that engender service classes that engender service events, where do the service universes come from? IBM Almaden Services Research ${ }^{1}$ and Fitzsimmons and Fitzsimmons have identified five dimensions along which we can classify services:

I. Service Process - using the degrees of Customer Interaction and Customization (by the provider) and Provider Judgment or Labor Intensity as metrics

II. Service Nature - using the Service Object and Service Result as metrics

III. Service Delivery - using Service Scheduling and Service Mode (continuous or discrete) as metrics

IV. $\quad$ Service Availability - using Service Site and Service Execution (who travels) as metrics

V. Service Demand - using Demand Fluctuation and Service Capacity as metrics

We can use the five dimensions as service model generators.

\section{Service Process}

Each dimension can be conceptualized as one view of a class of service models, and collectively, the five dimensions define a service universe. It is useful to think of the service universe as a point of view regarding the multiplicity of services that exist in a socially-constructed world. The Service Process dimension is employed as an introductory example. Process ${ }^{2}$ :

Here is how it works. Each dimension can be viewed as a matrix, such as the following for Service

\footnotetext{
1 IBM Almaden Services Research, "SSME: What are services?" http://almaden.ibm.com/ssme, 2006.

2 The service diagrams in the IBM report are adapted from Fitzsimmons and Fitzsimmons (see selected readings).
} 


\begin{tabular}{|c|c|c|}
\hline & Custom & Customization \\
\hline & Low & High \\
\hline 氖䒠 & $\begin{array}{l}\text { Airline } \\
\text { Hotel }\end{array}$ & $\begin{array}{l}\text { Hospital } \\
\text { Auto repair }\end{array}$ \\
\hline 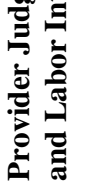 & $\begin{array}{l}\text { Retail } \\
\text { School }\end{array}$ & $\begin{array}{l}\text { Doctor } \\
\text { Lawyer }\end{array}$ \\
\hline
\end{tabular}

Each quadrant suggests a different service model, and the contents of that quadrant are examples of that type of service arrangement. Clearly, this is a very good start to defining classes of service, but there are a few open items, such as the specification of the service object on which the service is performed. Accordingly, the Service Process is a necessary condition but not a sufficient condition for defining a service model.

The service metrics deserve some consideration. The Customer Interaction and Customization metric refers to the degree of specific attention given by the provider to the client during the entire service event. When a client engages an airline seat or a hotel room, the facility is one of a select few possibilities and only a requisite amount of service is given to the client afterwards. With hospital service or auto repair, the service is unique to each client. The Provider Judgment or Labor Intensity metric can refer to three possibilities: (1) The amount of time the client receives attention when in the service process; and (2) The amount of time the provider is giving service when in the service process; and (3) The level of knowledge the provider brings to the service event. The service metrics are not precise in all cases; but it should be noted that our ultimate objective is to identify classes of service and not describe specific service events. (This comment will apply to other service dimensions, as well.)

\section{Service Nature}

In order to achieve a greater degree of specificity, we can supplement the Service Process dimension with a Service Nature dimension, as follows ${ }^{3}$ :

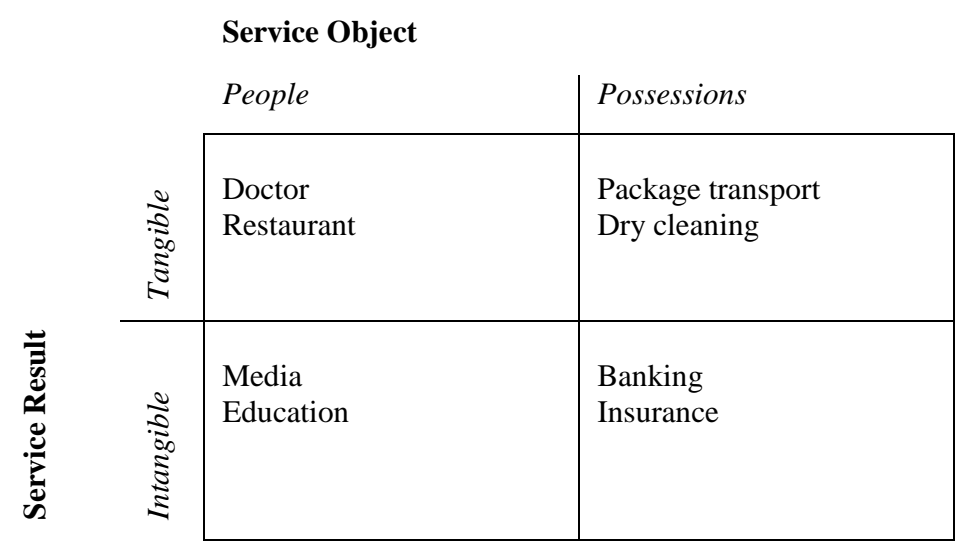

\footnotetext{
${ }^{3}$ Op cit. The remaining service matrices are summarized in the IBM report previously cited.
} 
Taking the services of a medical physician as an example, the service would be classified as follows:
Service Process: $\quad$ Provider Judgment or Labor Intensity (high),
$\begin{array}{ll} & \text { Client Interaction and Custe } \\ \text { Service Nature: } & \text { Service Result (tangible), }\end{array}$
Service Object (people)

As before, the characterizations of a physician's services to this point represent necessary conditions, but still not sufficient conditions ${ }^{4}$. We need the additional dimensions for a complete classification.

The service metrics for the dimension Service Nature should be mentioned. The Service Object metric refers to the object on which the service is performed, whether it is a person or a possession belonging to a service entity. Recall that if the service object is information, it would belong to the possession category. The Service Result metric can refer to two possibilities: (1) In the case of a person object, it refers to whether the service affects a person's physical presence, or it affects a person's mind; and (2) If the service object is a possession, it refers to whether the result is something one can usually observe.

\section{Service Delivery} follows:

The Service Delivery dimension reflects Service Scheduling and Service Mode (discrete or continuous) as

\begin{tabular}{|c|c|c|}
\hline & Service Schedt & \\
\hline & Formal & Informal \\
\hline 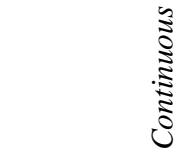 & $\begin{array}{l}\text { Utilities } \\
\text { Internet }\end{array}$ & $\begin{array}{l}\text { Radio/TV } \\
\text { Police }\end{array}$ \\
\hline 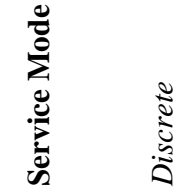 & $\begin{array}{l}\text { Doctor } \\
\text { Lawn mowing }\end{array}$ & $\begin{array}{l}\text { Pay phone } \\
\text { Restaurant }\end{array}$ \\
\hline
\end{tabular}

The Service Delivery dimension reflects whether the provider specifically knows the client or schedules the service in advance (Service Scheduling) and whether the service has specific start and stop times or is a form of continuous service (Service Mode). Continuing with the physician example, we can specify the nature of the service with three dimensions as follows:

$\begin{array}{ll}\text { Service Process: } & \begin{array}{l}\text { Provider Judgment or Labor Intensity (high), } \\ \text { Client Interaction and Customization (high) }\end{array} \\ \text { Service Nature: } & \begin{array}{l}\text { Service Result (tangible), } \\ \text { Service Object (people) } \\ \text { Service Delivery: }\end{array} \\ \begin{array}{l}\text { Service Scheduling (formal), } \\ \text { Service Mode (discrete) }\end{array}\end{array}$

${ }^{4}$ See Sampson and Froehle (2006). 
Clearly, there are edge cases in this form of analysis, but the design, even at this point, is almost precise enough to delineate a Service Universe.

\section{Service Availability}

The Service Availability dimension specifies the Service Site where a service event is executed and which entity in the service relationship travels to effect the service (Service Execution), as follows:

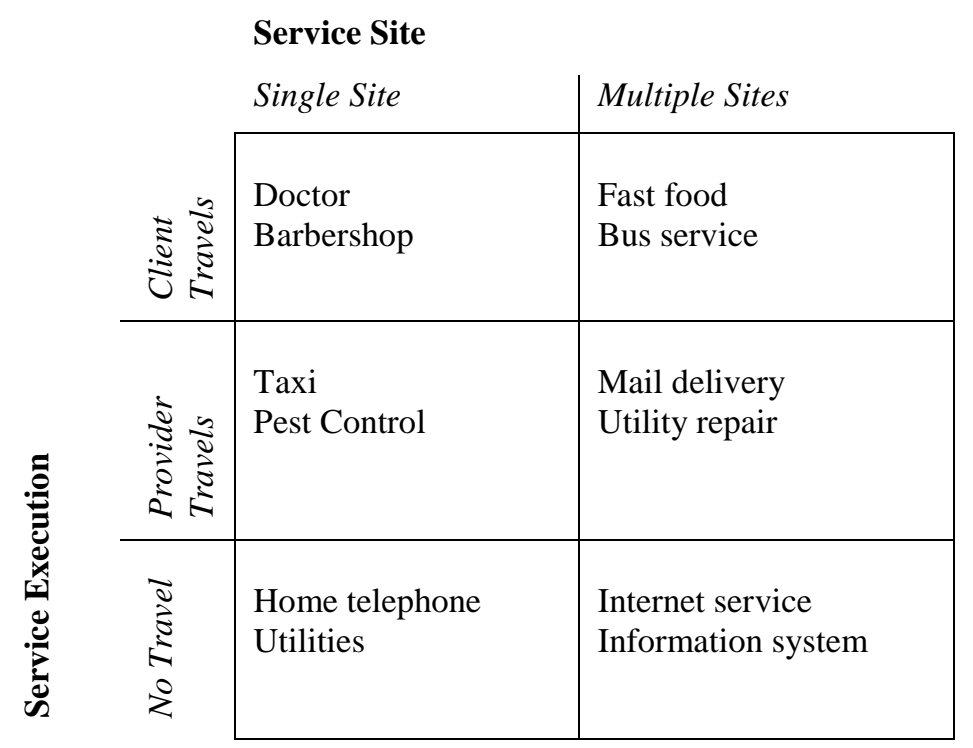

This dimension gives evidence as to where a service takes place and the manner in which the service is arranged. follows:

Continuing with the physician example, we can specify the nature of the service with four dimensions as

Service Process: $\quad$ Provider Judgment or Labor Intensity (high),

$\begin{array}{ll} & \text { Client Interaction and Custor } \\ \text { Service Nature: } & \text { Service Result (tangible), }\end{array}$

Service Object (people)

Service Delivery: Service Scheduling (formal),

Service Mode (discrete)

Service Availability: Service Site (single site),

Service Execution (client travels)

It is evident at this point that a service model for medical provisioning is clearly beginning to unfold.

\section{Service Demand}

Service Demand refers to the degree to which demand for service fluctuates and the capacity of the service provider to satisfy variation in client needs for service: 


\begin{tabular}{|c|c|c|c|}
\hline & & Demand Fluctu & \\
\hline & & Wide & Narrow \\
\hline & $\frac{\frac{0}{\pi}}{\frac{\pi}{3}}$ & $\begin{array}{l}\text { Utilities } \\
\text { Police }\end{array}$ & $\begin{array}{l}\text { Insurance } \\
\text { Banking }\end{array}$ \\
\hline 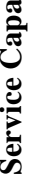 & 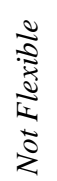 & $\begin{array}{l}\text { Tax preparation } \\
\text { Hotel }\end{array}$ & $\begin{array}{l}\text { Doctor } \\
\text { Theatre }\end{array}$ \\
\hline
\end{tabular}

Service Demand is a composite dimension because it reflects the degree of client demand and the capacity of the service provider to respond to demand changes. In a limited sense, demand fluctuation is always predictable. For example, doctor visits are usually up after a holiday or a weekend because people have an opportunity to think about their ills. However, the real question relates to peak demand and the flexibility inherent in service delivery. Some services can manage demand by scheduling and manage capacity by hiring part-time employees. Service Demand applied to the physician example yields the following list:

$\begin{array}{ll}\text { Service Process: } & \begin{array}{l}\text { Provider Judgment or Labor Intensity (high), } \\ \text { Client Interaction and Customization (high) }\end{array} \\ \text { Service Nature: } & \begin{array}{l}\text { Service Result (tangible), } \\ \text { Service Object (people) }\end{array} \\ \text { Service Delivery: } & \begin{array}{l}\text { Service Scheduling (formal), } \\ \text { Service Mode (discrete) }\end{array} \\ \text { Service Availability: } & \begin{array}{l}\text { Service Site (single site), } \\ \text { Service Execution (client travels) }\end{array} \\ \text { Service Demand: } & \begin{array}{l}\text { Demand Fluctuation (narrow), } \\ \text { Service Capacity (not flexible) }\end{array}\end{array}$

The physician example is complete in the sense that we have created a conceptual view of a medical provisioning service along the five dimensions.

\section{Service Considerations}

It is important to recognize that a service model is not normative in any sense of the word. As an example, it doesn't tell you whether to go to a physician or a chiropractor. It doesn't tell you how to combine services or develop a service system. A service model defines one point in a five dimensional Cartesian space representing a class of services. What about service innovation? Simply go to a point in the space that is not represented and there is your innovation. There is of course much more to service innovation, but this is the basic idea.

\section{THE DNA OF SERVICES}

The previous section introduced the notion of a five dimensional Cartesian space used to represent services and establish service models. An appropriate name for this space is a service hyperspace, because that is what it is. In this section, we are going to introduce how the service hyperspace can be used to uniquely define classes of service. The DNA of services ${ }^{5}$ is used to delineate points in the service hyperspace.

\footnotetext{
${ }^{5}$ In this instance, DNA is an acronym recursively defined as "DNA is Never Ambiguous."
} 


\section{Characterization Of The Service Matrices}

It is useful to characterize the information inherent in a service matrix as a set of quadrants, as follows:

Column Metric

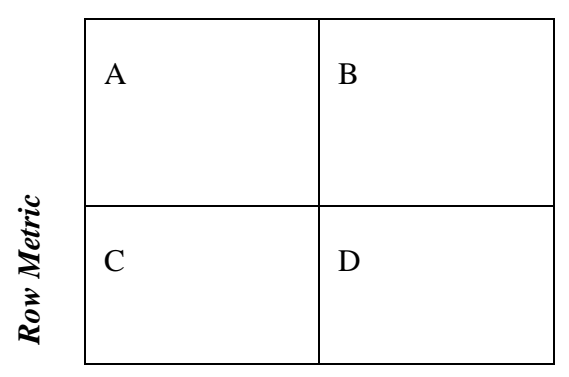

Column Metric

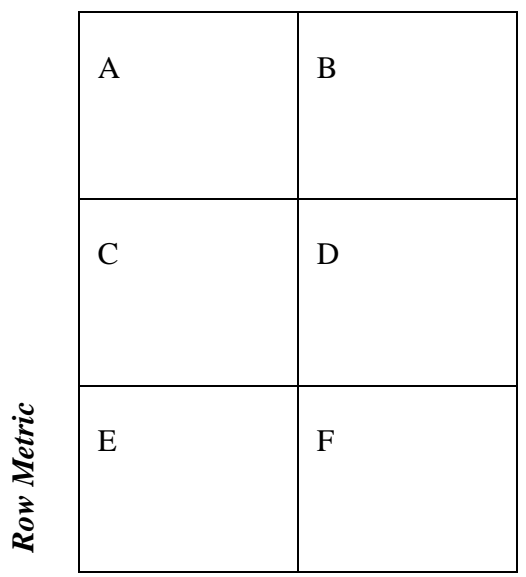

Super imposing the set of quadrants on the Service Process matrix, for example, is reflected in the following diagram:

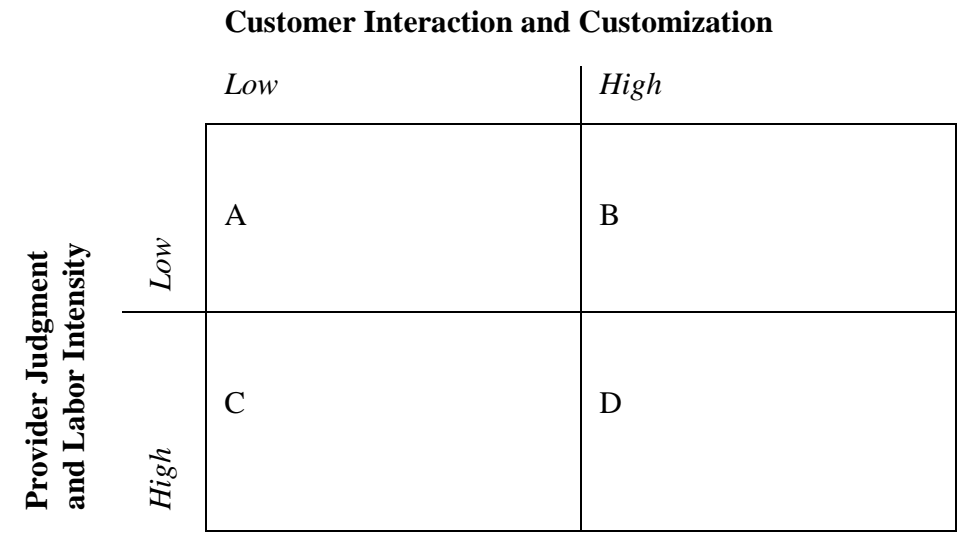

Quadrant A represents a $\boldsymbol{L o w}$ value for the Customer Interaction and Customization (CIC) metric and a Low value for the Provider Judgment or Labor Intensity (PJL) metric. Similarly, quadrant D represents a High CIC value and a High PJL value, and so forth. The next step is to map the quadrants to a linear scale for representation in a service hyperspace.

\section{Linear Scales}

Continuing with the Service Process example, a service with High CIC and Low PJL values is given a linear value of B on the following linear scale: 


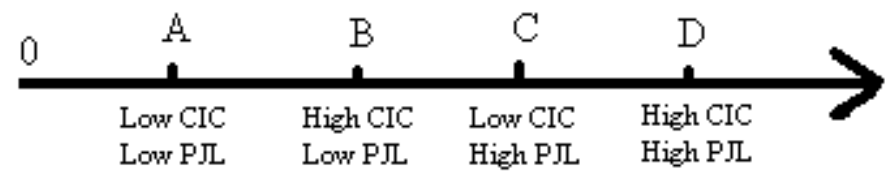

Table 1 gives the linear scales for the five dimensions in the service linear hyperspace. Each dimension has a linear scale based on the values for the associated metrics. Consider, for example, dimension \#2 Service Nature. If the value for the Service Result metric is Tangible and the value for the Service Object metric is Possession, then the linear scale value for dimension \#2 Service Nature is B.

Here is where the service DNA sequence comes in. Each service model has a unique DNA sequence, based on the linear scale values for each of its dimensions. Moreover, the various dimensions have an order based on the dimension numbers given in Table 1.

Recall the physician example given earlier and summarized here:

Service Process: $\quad$ Provider Judgment or Labor Intensity (high), Client Interaction and Customization (high)

Service Nature: $\quad$ Service Result (tangible),

Service Object (people)

Service Delivery: $\quad$ Service Scheduling (formal), Service Mode (discrete)

Service Availability: Service Site (single site), Service Execution (client travels)

Service Demand: Demand Fluctuation (narrow), Service Capacity (not flexible) 
Dimension \#1: Service Process

$\underline{\text { Provider Judgment/Labor Intensity }} \underline{\text { Customer Interaction/Customization }} \underline{\text { Linear Scale }}$

\begin{tabular}{lll} 
Low & Low & A \\
Low & High & B \\
High & Low & C \\
High & High & D \\
\hline
\end{tabular}

Dimension \#2: Service Nature

$\underline{\text { Service Result }}$

\section{$\underline{\text { Service Object }}$}

People

Possessions

People

Possessions

\section{$\underline{\text { Linear Scale }}$}

A

B

C

$\mathrm{D}$

Dimension \#3: Service Delivery

$\begin{array}{lll}\text { Service Mode } & \text { Service Scheduling } & \text { Linear Scale } \\ \text { Continuous } & \text { Formal } & \text { A } \\ \text { Continuous } & \text { Informal } & \text { B } \\ \text { Discrete } & \text { Formal } & \text { C } \\ \text { Discrete } & \text { Informal } & \text { D }\end{array}$

Dimension \#4: Service Availability

$\underline{\text { Service Execution }}$

Client Travels

Client Travels

Provider Travels

Provider Travels

No Travel

No Travel $\underline{\text { Service Site }}$

Single Site

Multiple Sites

Single Site

Multiple Sites

Single Site

Multiple Sites

\section{$\underline{\text { Linear Scale }}$}

A

B

C

D

E

F

\section{Dimension \#5: Service Demand}

$\underline{\text { Service Capacity }}$

Flexible

Flexible

Not Flexible

Not Flexible
Demand Fluctuation

Wide

Narrow

Wide

Narrow

\section{$\underline{\text { Linear Scale }}$}

A

B

C

D

Table 1: Linear Scales for the Five Dimensions in Service Hyperspace.

From Table 1, dimension \#1 (Service Process) has a DNA sequence value of D, because its value for the metric Provider Judgment or Labor Intensity is High and the value for the metric Client Interaction and Customization is also High. Similarly, dimension \#2 (Service Nature) has a DNA sequence value of A, because its value for the 
metric Service Result is Tangible and the value for the metric Service Object is People. Using the same thinking, dimension \#3 (Service Delivery) has a DNA sequence value of C; dimension \#4 (Service Availability) has a DNA sequence value of A; and finally, dimension \#5 (Service Demand) has a DNA sequence value of D. So the complete service DNA sequence for the physician model is DACAD.

\section{Additional Examples Of Service DNA Sequences}

The service customarily known as "lawn mowing" is represented by the following script:

$\begin{array}{ll}\text { Service Process: } & \begin{array}{l}\text { Provider Judgment or Labor Intensity (high), } \\ \text { Client Interaction and Customization (low) }\end{array} \\ \text { Service Nature: } & \begin{array}{l}\text { Service Result (tangible), } \\ \text { Service Object (possession) }\end{array} \\ \text { Service Delivery: } & \begin{array}{l}\text { Service Scheduling (formal), } \\ \text { Service Mode (discrete) }\end{array} \\ \text { Service Availability: } & \begin{array}{l}\text { Service Site (single site), } \\ \text { Service Execution (provider travels) }\end{array} \\ \text { Service Demand: } & \begin{array}{l}\text { Demand Fluctuation (narrow), } \\ \text { Service Capacity (not flexible) }\end{array}\end{array}$

The key attributes of this kind of service is that the provider travels and performs the service on a possession of the client. The labor intensity is high but the service in normally not customized for each client. The activity is scheduled and takes a finite time. The demand doesn't vary and the provider usually has a limited capacity to perform the service. The service DNA sequence for this service model is CBCCD.

Next, consider a "hotel" example, characterized as follows:

$\begin{array}{ll}\text { Service Process: } & \begin{array}{l}\text { Provider Judgment or Labor Intensity (low), } \\ \text { Client Interaction and Customization (low) } \\ \text { Service Result (tangible), } \\ \text { Service Nature: }\end{array} \\ \text { Service Delivery: } & \begin{array}{l}\text { Service Sched (people) } \\ \text { Service Mode (discrete) }\end{array} \\ \text { Service Availability: } & \begin{array}{l}\text { Service Site (single sites), } \\ \text { Service Execution (client travels) }\end{array} \\ \text { Service Demand: } & \begin{array}{l}\text { Demand Fluctuation (wide), } \\ \text { Service Capacity (not flexible) }\end{array}\end{array}$

The key attributes in this example are that the client travels, customization is low, and the result is tangible because the client uses the hotel's facilities for a prescribed period of time. Clearly, the service object is people, the service is scheduled, and the activity is discrete. The service capacity is fixed even though there may be wide demand fluctuation. The service DNA sequence for this model is AACAC.

\section{MODELS, CLASSES, AND OBJECTS}

Each service model can be uniquely identified by a service DNA sequence. But, what if two models have the same DNA sequence? It could easily happen since many services have the same signature, as in the following examples:

Medical provisioning: doctor, dentist, chiropractor

Transportation: airline, bus

Home service: lawn mowing, gutter cleaning, window washing 
If two service models have the same service DNA sequence, then they are in the same class, as defined previously. Recall, that the term "service model" is used to represent a template for a class or an object - whatever is appropriate at the moment.

We can also construct a service DNA sequence representing a service class with no instances (i.e., objects). Because service systems are socially constructed forms of knowledge, we are not constrained by nature to describe only what exists. We can be innovative and design service systems to satisfy a variety of needs.

\section{FUTURE RESEARCH}

Service systems are assimilated from objects in a service universe. A methodology similar to the DNA of services is needed to formalize service systems in order to completely develop a science of services.

\section{REFERENCES}

1. Fitzsimmons, J.A. and M.J. Fitzsimmons, Service Management: Operations, Strategy, Information Technology $\left(5^{\text {th }}\right.$ Edition), New York: McGraw-Hill Irwin, 2006.

2. IBM Almaden Services Research, SSME: What are services? http://almaden.ibm.com/ssme, 2006.

3. Katzan, H., A View of Services Science, Southeast Decision Science Institute, Savannah, GA, February 2123, 2007.

4. Katzan, H., A Client's View of Service Systems, Decision Science Institute Mini Conference on Service Science, Carnegie Mellon University, Pittsburgh, PA, May 24-26, 2007.

5. Katzan, H., A Client's View of the Quality of Service Systems, Decision Science Institute Mini Conference on Service Science, Carnegie Mellon University, Pittsburgh, PA, May 24-26, 2007.

6. Katzan, H., Foundations of Complex Adaptive Service Systems, International Decision Science Institute, Phoenix, AZ, November 17-20, 2007.

7. Katzan, H., A Reductionist Approach to Service Systems, International Decision Science Institute, Phoenix, AZ, November 17-20, 2007.

8. Maglio, P.P. and J. Spohrer, Fundamentals of Service Science, IBM Almaden Research Center, San Jose, CA, 2007.

9. Martin, J. and J.J. Odell, Object-Oriented Methods: A Foundation ( $2^{\text {nd }}$ Edition), Upper Saddle River, NJ: Prentice Hall PTR, 1998.

10. Sampson, S.E. and C.M. Froehle, Foundations and Implications of a Proposed Unified Services Theory, Production and Operations Management, Vol. 15, No. 2 (Summer, 2006), pp. 329-343.

11. Spohrer, J., Maglio, P.P., Bailey, J., and D. Gruhl, Steps Toward a Science of Service Systems, IBM Research, Almaden Research Center, San Jose, CA, www.almaden.ibm.com/asr, 2007. 
NOTES 